\title{
Mind-Mapping Technique Implementation into English for Specific Purposes Training
}

\author{
Nina Tverezovska', Maryna Rebenko ${ }^{2}$, Victor Rebenko ${ }^{3}$, Maxim Roganov ${ }^{4}$, Tamara Otroshko ${ }^{4}$, \\ Victoriia Domina ${ }^{5}$, Oleksandra Islamova ${ }^{6}$, Ihor Bloshchynskyi ${ }^{6, *}$ \\ ${ }^{1}$ Department of Social Work and Social Rehabilitation, Faculty of Humanities and Pedagogy, National University of Life and \\ Environmental Sciences of Ukraine, Kyiv, 03041, Ukraine \\ ${ }^{2}$ Department of Foreign Languages of Mathematical Faculties, Taras Shevchenko National University, Institute of Philology, Kyiv, \\ 39745, Ukraine \\ ${ }^{3}$ Department of Livestock Mechanization, Faculty of Mechanical and Technology, National University of Life and Environmental \\ Sciences of Ukraine, Kyiv, 03041, Ukraine \\ ${ }^{4}$ Department of Mathematics and Physics, Faculty of Social Pedagogical Sciences and Foreign Philology, Municipal Establishment \\ "Kharkiv Humanitarian Pedagogical Academy" of Kharkiv Regional Council, Kharkiv, 61050, Ukraine \\ ${ }^{5}$ Department of English Philology, Faculty of Humanities and Pedagogy, National University of Life and Environmental Sciences of \\ Ukraine, Kyiv, 03041, Ukraine \\ ${ }^{6}$ Department of Foreign Languages, Bohdan Khmelnytskyi National Academy of the State Border Guard Service of Ukraine, \\ Khmelnytskyi, 29000, Ukraine
}

Received September 2, 2020; Revised November 10, 2020; Accepted November 19, 2020

\section{Cite This Paper in the following Citation Styles}

(a): [1] Nina Tverezovska, Maryna Rebenko, Victor Rebenko, Maxim Roganov, Tamara Otroshko, Victoriia Domina, Oleksandra Islamova, Ihor Bloshchynskyi, "Mind-Mapping Technique Implementation into English for Specific Purposes Training," Universal Journal of Educational Research, Vol. 8, No. 12A, pp. 7379 - 7393, 2020. DOI: 10.13189/ujer.2020.082522.

(b): Nina Tverezovska, Maryna Rebenko, Victor Rebenko, Maxim Roganov, Tamara Otroshko, Victoriia Domina, Oleksandra Islamova, Ihor Bloshchynskyi (2020). Mind-Mapping Technique Implementation into English for Specific Purposes Training. Universal Journal of Educational Research, 8(12A), 7379 - 7393. DOI: 10.13189/ujer.2020.082522.

Copyright $\subseteq 2020$ by authors, all rights reserved. Authors agree that this article remains permanently open access under the terms of the Creative Commons Attribution License 4.0 International License

\begin{abstract}
The conducted research reveals the efficacy of a mind-mapping training technique within the English for Specific Purposes university course. The study aims at assessing the influence of mind maps on the students' motivation and language academic performance. To achieve the objective, it became relevant to study the step-by-step educational development of a university entrant, junior student and, then, a graduate as the result of practicing mind-mapping activities in classes. To accomplish the research tasks successfully it was necessary to apply the following methods: observation research, questioning, testing, output data calculating, modelling, foreseen data checking. The methods of statistical analysis, namely: data correlation, factor analysis, consequent implication, and content analysis were chosen. The three-stage experiment was fulfilled within the 2016-2018 academic years at the Faculty of Computer Sciences and Cybernetics (Taras Shevchenko National University of Kyiv, Ukraine) and encompassed
\end{abstract}

three groups of participants namely, the university entrants, the students of the first and fourth years of study. The research results show foreign language academic proficiency enhancement. The data prove that the respondents from the experimental research groups (in contrast to the control groups' outcomes) considered mind-mapping activities interesting and engaging. Such a learning motivation boost is due to the participants' associative, spatial and geometric thinking ability activation. Further investigation correlating students' motivation and mind maps' content is needed to facilitate the English for Specific Purposes university training.

Keywords Mind Maps, English For Specific Purposes, Students' Motivation, Language Performance, Questionnaire and Testing Methods, Non-traditional Training Techniques 


\section{Introduction}

At the current stage of information and technological society development, there is a necessity to achieve a new quality-featured direction of education development. It concerns the high school, in particular. The Ukrainian market of highly qualified specialists is unique, and standard analytical tools cannot effectively define it. On the one hand, today's graduates are offered a wide range of career opportunities, and on the other hand, it is rather difficult to make a generalization of qualification requirements for a job candidate. However, it becomes possible to highlight some general characteristics. Nowadays, thanks to the process of European integration, most employers demand strong critical thinking, fast data analysis skills, and highly appreciate innovation and technological awareness, as well as the ability to problem-solve successfully. It is also clear that intellectual globalization is accelerating so that introduction of the advanced methods and practices within higher education should be implemented simultaneously with the latest integrative technological innovations. Studying the ways to solve this issue efficiently, we made an effort to apply a mind-mapping technique as "one of the most interesting ways of introducing training issues in class, as well as systematization of a student's self-studying process" (Tverezovska, 2017, p. 278).

The mind-mapping technique (note that such concepts as "mental map", "associative diagram”, "spider diagram”, "radial tree", "visual map”, or "concept map" could also refer to the principles of "mind maps") aims, first of all, to optimize the process of assimilating and structuring new material, and to make it more visual and understandable for the student. It is possible to accomplish the above goals successfully, because the so-called "step forward from one-dimensional to multi-dimensional thinking process" (Tverezovska, 2017, p. 283) coincides with the structure of neuronal systems of human brain. Consequently, the brain's natural function to think associatively (or radiantly) is activated (Novak, Cañas, 2008 , p. 8-10). It is easy to perceive and remember such visual spatial models, because these so-called graphical communication schemes are composed in correspondence with "the human brain language" (Tolman, 1948, p. 203204; Downs, Stea, 1977, p. 55-60; Schenk, 2013, p. 2-4).

It is worth noticing that tomorrow's graduates of the Faculties of Computer Sciences and Cybernetics, and Information Technologies have gained profound knowledge in such fields as System Sciences and Cybernetics, Software Engineering, Artificial Intelligence, as well as Computer Science and Computational Technologies. They are trying to be successful in developing new approaches to current applications and systems. In addition to professional skills, a high level of foreign language (FL) proficiency is one of the priority requirements of today's labor market. That is why the students consider their language competence to be crucial for future employment, career opportunities and income level. Therefore, they apply new training approaches and activities, especially within the English for Specific Purposes (hereinafter ESP) university course.

\subsection{The Aim}

The purpose is to conduct the experimental study and make an analysis of the mind maps' implementation into the ESP training course at Taras Shevchenko National University of Kyiv, Ukraine. To achieve the objective, it became relevant to study the step-by-step educational development of a university entrant, junior student and, then, a graduate as the result of practicing mind-mapping activities in classes.

\section{Materials and Methods}

\subsection{Literature Review}

According to Laurence Anthony (Anthony, 2018, p. 18), Professor of Applied Linguistics, Faculty of Science and Engineering (Waseda University, Japan), with his 25-year experience as the Director of the Center for English Language Education in Science and Engineering (CELESE), the concept of "ESP course" is defined as a specific "approach to teaching" or a certain "attitude of mind" (Anthony, 2018, p. 18) with the reference to the idea of the ESP Journal's co-editor Tony Dudley-Evans (UK).

Since the early 1960s, ESP course has become one of the most effective methods of teaching English as a FL. This fact is evidenced by the increasing number of the world universities offering ESP Master's Programs (for example, the University of Birmingham and Aston University (UK), the University of Florida English Language Institute and the University of Southern Indiana (US)), as well as the number of language centers, introducing ESP courses for foreign students in English-speaking countries. It is also worth emphasizing the above-mentioned English for Specific Purposes Journal, dedicated to discussing ESP issues (Journals.elsevier.com website), as well as a couple of international groups such as ESG SIG (Special Interest Groups) with the blogs IATEFL (International Association of Teachers of English as a Foreign Language) and TESOL (Teaching English to Speakers of Other Languages), known for their international online conferences. Analyzing the recent studies conducted in 2016 by the authors of the ESP Journal that are relevant to our research, we can highlight the papers of Kaisheng Huang (Huang, 2016), Neil H. Johnson and Paul A. Lyddon (Johnson, Lyddon, 2016), in which the authors reveal the results of their pilot projects on the development of new techniques for mastering English by foreign 
students. In fact, one of the challenges in FL training for Pr. Neil Johnson's and Pr. Paul Lyddon's students (Johnson, Lyddon, 2016) seems to be the rules of grammar due to the linguistic and cultural peculiarities of the target culture of Japan. As for the current students and university entrants of Ukraine, participated in our research, they are much more in need of implementing innovative methods of practicing and mastering lexical material rather than grammatical one. It concerns, in particular, the professional field of communication.

The idea to present a thought like a model or diagram, in which a set of "rays" (information modes) diverges from the central concept in different directions, is not new. It was referred to by the following prominent figures, such as the philosopher Porfirius of Tyros (III century AD, the notes on the concept of Aristotle's categories), the philosopher Raymond Lulli (XIII century, the logical operation simulation technique), Leonardo da Vinci (XV century, graphic records of the scientific-technical content as the basis of experimental art), Albert Einstein (XX century, the relativity theory modelling), Pablo Picasso (XX century, scheme drawings, cubic forms), Paul Klee (XX century, the art theory in the form of graphic-spatial images and schemes), Sir Winston Churchill (XX century, Churchill's famous schemes and models) and others.

In recent studies of some Ukrainian scholars and lecturers, for example (Pozdniakova, 2018, p. 7; Shakhina, Miedviediev, 2015, p. 74; Kolesnyk, 2012, p. 135; Mashkina, 2011, p. 62), T. Buzan, the well-known English psychologist, is often considered to be the founder of the mind-mapping technique. However, from our point of view, it is the American psychologist and teacher David Ausubel (Tverezovska, 2017, p. 283), who proclaimed the theory of assimilation of new ideas and concepts through the already existing and well-known ones (see David Ausubel's concepts of the "advance organizer model", "comparative and expository advance organizers" (Ausubel, 1968, p. 6).

Later on, this theory was developed in a number of similar ideas. Professor Joseph D. Novak, (Cornell University, US), for example, introduced the rules for creating and designing concept maps, i.e. in chains of events, clusters, compare/contrast schemes, problem-solution cycles, family trees, fishbones, etc. He also described their practical application as a means of visualization and working out new ideas (see Joseph D. Novak's "concept mapping” (Novak, Cañas, 2008)). A correlating notion, "cognitive map", was offered for the first time by Edward Tolman, who described its principles on the example of the functioning multiple nerve bonds during his experiments on laboratory rats (Tolman, 1948). In 2007 S.Tümen and M.Taşpinar were first to use concept maps in FL teaching, particularly in training grammar (Tümen, Taşpinar, 2007). Turkish scholars encouraged the students of the 9th Year to learn English tenses by drawing family tree maps. In D. Šulovská's experience, for instance, concept maps should be constantly implemented in ESP classroom activity because they are exactly the means to improve students' FL skills, particularly of the political sciences' department (Šulovská, 2010).

However, the definition of "mind maps" concept given by Roger Downs in collaboration with David Stea (Downs, Stea, 1977) is considered to be fundamental. The researchers refer mind maps to an image of a certain part of the environment that a person depicts in imagination (Downs, Stea, 1977, p. 23).

The works of the well-known English psychologist $T$. Buzan, the author of considerable memory boosting and speed reading techniques, the founder of the Mind Sports Organization Company, popularized the theory of mind-mapping the most. In his papers Use Your Head (1974), Speed Memory (1977), Make the Most of Your Mind (1984), the researcher described the process of simulation and practical application of mind maps aimed at solving whatever intellectual task in business, science and education, and also developed the notions of "planning", "idea generation", "brainstorming", "presentation”, etc. As a result, such T. Buzan's techniques and methods have been popularised through the development of a number of computer programmes like iMindMap, Mindmeister, XMind, LOOPY and others.

In the 1980s, the technique of training intensification by means of reference signals (i.e. a set of scheme models presenting educational material) was introduced by the honoured teacher of the Ukrainian SSR Viktor F. Shatalov (Shatalov, 1989). Next decade, the research papers of P. Drucker, B. Santo, S. B. Twiss and J. Schumpeter on the introduction of mind maps founded the theory of innovation.

The Ukrainian secondary school of today actively have learned from the experience of foreign colleagues, the pedagogical practice of Graham Wheeler, in particular. Mr. Wheeler, the head of the chemistry department of the Herschel Grammar School in England, has been teaching chemistry using mind-mapping techniques for five years. As a result, the average proportion of school leavers, who successfully passed entrance university exams, is $98 \%$. So, on I. Chereshniuk's web page (Irinaclass12.dp.ua website), a primary school teacher at the Secondary School of Novomykolaivsk (Ukraine), the methodological papers on certain topics, projects, and self-studying exercises in the format of mind maps are widely presented. Mrs. Chereshniuk describes the techniques in detail and shares her own experience on their implementation at the lessons. Moreover, it is emphasized that such an innovation aims at assisting the teacher and improving the educational process quality. The teachers of another Ukrainian school (Secondary School of Novosilky, Ukraine) actively apply the free online service http://bubbl.us/, which provides an opportunity to organize asynchronous team preparation of 
training papers. As for the implementation of the mind-mapping technique in higher schools of Ukraine, it is not as active and efficient as at the corresponding secondary schools. According to V. Mashkina's study of the benefits of using mind maps in the educational process of geographers (Mashkina, 2011), it is truly claimed that the process of the mind-mapping technique's introduction at the today's high school of Ukraine is considerably slowing down due to the lack of state financing. Some details on these issues, concerning problem analysis mind map "Cross Border Procedure Detailed Analysis" using to intensify the learning process in the English class can be also found in the work of M. Karpushyna, I. Bloshchynskyi, A. Nakonechna, K. Skyba (Karpushyna, Bloshchynskyi, Nakonechna, Skyba, 2019, p 2713).

Therefore, most researchers agree that mind-mapping is a convenient and effective method of human visual perception and a user-friendly way of a schematic recording of ideas, notions and concepts that reflects associative connections in human brain (Pak, 2010, p. 4; Schenk, 2013; Woolfolk, Winne, Perry, \& Shapka, 2010). Such a method of "curtailing" huge blocks of information to the most important concepts can be a so-called "motivator" for intensive learning and successful replacement of traditional text notes (Tverezovska, 2017, p. $279,287,362)$.

\subsection{Unsolved Issues}

Today's challenges force teachers to look for innovative ways of presenting educational material. Unfortunately, it is becoming increasingly common that most students lack the motivation to study due to uninteresting topics or boring classes. While developing innovative training techniques, it is precisely the motivation itself that serves as the driving force aimed at catching the student's cognitive interest to study. It is well-known that motives encompass two types - cognitive and social. The motive forms the background of any action of a personality as a particular individual need to satisfy personal interests, aspirations or beliefs. For instance, the interests of the students and university entrants participated in the research conducted, turned into the motives towards productive cognitive activity, that is, more profound learning of the English language. Concerning the junior students, they were featured by cognitive motives and emotionally vivid interest to the training material. If such a motive of a cognitive activity is inherent in a group of participants (university entrants and junior students, in particular), then the university graduates are also motivated in a social way, strongly willing to professional successful employment under up-to-date labour market conditions. The research group of the Bachelor's Program students showed desire to successfully graduate from the university and start working on their specialty.
The ESP training course, aimed at further career success of a university graduate, makes the lecturers look for new techniques and methods of teaching constantly and persistently.

Nowadays, the use of multimedia or role-play activities in class does not ensure teachers the desired progress, because the information learning takes a linear direction. Therefore, in order to achieve the final goal - to motivate the students to perceive, cope with the material and increase their level of language proficiency - more and more techniques of radiant training (particularly, mind-mapping) are being introduced. Hence, we found it relevant to work out this advanced world-wide training technique and to monitor its implementation not only among the first and fourth-year students, but also in university entrants' classes aimed at obtaining more vivid results, enriching the common methods of the ESP teaching with the latest innovative solutions.

In the research, the working hypothesis suggests that the implementation of mind-mapping teaching technique within the ESP university course will enable to intensify the learning process and enhance both language skills and motivation of the students with different levels of FL proficiency.

\subsection{Methods}

To accomplish the research tasks successfully it was necessary to apply the following techniques: observation research, questioning, testing, output data calculating, modelling, prospect forecasting, foreseen data checking. The methods of statistical analysis, namely: data correlation method, factor analysis method, consequent implication method, and content analysis method were also applied.

Participants. Let us review the stages of the experiment conducted during 2016-2018 at Taras Shevchenko National University of Kyiv. The audience under the investigation encompassed three groups of participants, namely: 1) the university entrants, who took the entrance exam preparation (in Ukraine - the External Independent Testing (EIT)) course at the Preparatory Department (see the website http://pv.univ.kiev.ua) and nearly half of whom planned to apply for the Faculty of Computer Sciences and Cybernetics (the number of participants was 116, namely, 58 - in control groups and 58 - in experimental ones); 2) the first-year students of the Faculty of Computer Sciences and Cybernetics (196 participants, namely, 98 - in control groups and 98 - in experimental ones); 3) the fourth-year students of the same Faculty acquiring the Bachelor's degree in Computer Science and Software Engineering specialities (35 participants, namely, 17 - in control groups and 18 in experimental ones). In total, the experiment involved 347 participants.

Such student groups for the investigation were chosen 
on purpose. According to the Ministry of Education and Science of Ukraine (https://www.education.ua/articles/116/), IT engineers and software developers are the top ranking most relevant professions at modern labour market. In addition to professional skills, applicants require job-focused language proficiency. That is why, in our research, the ESP training course is considered to be a crucial component of the educational process for the students of Applied Mathematics, Informatics, System Analysis, and Software Engineering specialties. This course enables to enhance a range of language proficiency skills in order to develop effective interaction within academic and professional environments. The ESP course covers 36 academic hours (1 ECTS credit) for the junior students (out of total 200 academic hours of the General English course in the first and second semesters and 144 academic hours (4 ECTS credits) in the seventh and eighths semesters for the fourth year students of the Faculty of Computer Sciences and Cybernetics at Taras Shevchenko National University of Kyiv (Rebenko, 2017, p. 4). Such quantitative curriculum aspect evidences the significance of the development of professional communication skills for Ukrainian higher school.

As the research apparatus we used MindMeister.com service (http://www.mindmeister.com) to create mind maps. Research materials included a questionnaire, an oral and written survey and a free opinion interview.

\subsection{Research Procedure}

It is worth mentioning that the experiment was conducted under natural conditions and did not interfere with any logic or the rules of the educational process. All student groups (within each research group) worked on the same textbooks and programs in accordance with the same theme-based schedule.

At the initial data collection stage of the experiment all academic groups had the same level of knowledge and skills. The first stage presupposed to work out a questionnaire applying to the method of monitoring the starting level of the university entrants' English (Research Group 1, aged 16-17), its gradual development and improvement of their language skills, as well as the effectiveness of practicing various exercises in class. To prove validity and reliability of the results' assessment, the questionnaire was compiled to identify the inclination and interests of the students while studying English. Ten open-ended questions enabled the respondents to formulate their own answers in as many details as they would like, i.e. the respondents were allowed to give answers freely. The questions aimed to find out the respondent's personal interest in learning English, the level of language fluency, the role of additional after-class speaking practice, ways of language mastering, teaching methods, implementation of both technological and methodological training innovations in classes, etc. The same principle of the open-ended question survey was applied to the second group of respondents (Research Group 2) - i.e. the first-year students of the mathematical specialties (aged 17-18), but they were polled orally. Each participant of the third survey group (Research Group 3) the students of the fourth year of the Faculty of Computer Sciences and Cybernetics of Taras Shevchenko National University of Kyiv (aged 20-21) - was interviewed individually.

Such a three-faceted research method is due to a number of factors as follows:

a) Research Group 1 was questioned anonymously in the form of a written survey which enabled minimize the influence of some psychological factors, such as adolescent uncertainty of personal choice, fear and anxiety to cause a teacher's negative reaction in case of potentially "irrelevant" responses to the questions;

b) Research Group 2 was polled orally as psychologically university enrolment makes a junior feel much more confident and assertive compared to a school leaver. Just because of the fixed personal contact between the students and the lecturer, after 100 hours of English practice the respondents felt calm and relaxed;

c) For Research Group 3, the students of the Bachelor's Program of the Faculty of Computer Sciences and Cybernetics, an anonymous interview was chosen deliberately. Tomorrow's university graduates seem to be complete individuals from both psychological and physical aspects; they are also quite experienced linguistically, as well as professionally. The respondents were not given any explanations or possible replies, but each participant responded in his/her particular manner.

At the second (formative) stage of the experiment, the participants were divided into control (C) and experimental (E) groups. The control groups practiced the traditional training activities, while the experimental ones undertook a mind-mapping technique. This stage ended up in testing the students' language proficiency development. The tasks were worked out according to the curriculum and the students' age.

It should be noted that for the university entrants the main task was to check their knowledge of vocabulary and grammar rules, the first-year students were tested in reading, and the Bachelor's Program students - in listening comprehension. The maximum number of test points was 20 for all groups of the respondents. The marking scale ranges from 0 to 20 and reflects the following assessment criteria: $0-5$ points mean 'unsatisfactory' or 'failing', 6-10 - 'satisfactory', 11-15 'good' or 'sufficient', 16-18 - 'very good' and 19-20 points denote 'excellent' academic performance.

To test the respondents of Research Group 1, the certain task was compiled according to the EIT Program on the English Language for would-be Ukrainian university 
entrants (see the full text of the program at http://testportal.gov.ua/progeng/). To be exact, the practice task corresponded with the format of the EIT Language Use part aimed at determining both the language skills' level and vocabulary and grammar comprehension quality, which enables the students to communicate freely. The students were to complete two types of exercises: firstly, they chose one correct option from a suggested range, then, they filled in the gaps.

The students of the first year were supposed to fill in the gaps reading activity on the given topic and fill in the correct sentence from the options to form a logical text. The assignment was compiled in accordance with the "Common European Framework of Reference for Languages: Learning, Teaching, Assessment” (Britishcouncil.org website), and the "Curriculum on English for Specific Purposes Courses for the Ukrainian Universities" (Vzvo.gov.ua website), which provide the students with the specialized university programmes on the certain major. While working out the assignment for the respondents from C1-4 and E1-4 of Research Group 2, we could not help taking into account the bulk of the recommendations suggested by the British Council of
Ukraine and given in the paper "English for Specific Purposes (ESP) National Curriculum for Universities” (Bakaeva, Borysenko, Zuenok, \& others, 2005).

The assignment for the students of the fourth year presupposed listening to the recording and watching the video on the professionally related topic 'Robotics' and choosing between true and false statements. False statements were to be changed into true ones. The after-watching activity was reinforced in a round-table talk according to methodological recommendations of the above-mentioned papers (Britishcouncil.org; Vzvo.gov.ua; Bakaeva, Borysenko, Zuenok, \& others, 2005). At the final stage of the experiment we made an analysis of the obtained results.

\section{Results}

When the detailed answers of the respondents were gathered, they were analysed, generalized and used in a closed-ended questionnaire, which contained a range of options to choose from (see Table 1). 
Table 1. Closed-Ended Questionnaire on the Peculiarities of the English for Specific Purposes Training Course (for the Students of Research Groups 1-3)

\begin{tabular}{|c|c|}
\hline $\begin{array}{l}\text { Answer the given-below questions and choose } \\
\text { only ONE option in each case }\end{array}$ & Possible answers \\
\hline $\begin{array}{l}\text { 1. Why do you personally need to study } \\
\text { English? }\end{array}$ & $\begin{array}{l}\square \text { to prepare and pass the External Independent Testing; } \\
\square \text { to feel free while online chatting with foreigners; } \\
\square \text { to avoid a language barrier while travelling abroad; } \\
\square \text { to study abroad; } \\
\square \text { to achieve successful career opportunities in the future. }\end{array}$ \\
\hline What is your English level proficiency? & $\begin{array}{l}\square \text { elementary, A1; } \\
\square \text { pre-intermediate, A2; } \\
\square \text { intermediate, B1; } \\
\square \text { upper-intermediate, B2; } \\
\square \text { advanced, C1. }\end{array}$ \\
\hline $\begin{array}{l}\text { 3. What, in your opinion, is the role of the } \\
\text { additional English practice besides the } \\
\text { compulsory university language courses? }\end{array}$ & $\begin{array}{l}\square \text { relevant; } \\
\square \text { obligatory; } \\
\square \text { unnecessary. }\end{array}$ \\
\hline $\begin{array}{l}\text { 4. What form would you like to study English } \\
\text { at university? }\end{array}$ & $\begin{array}{l}\square \text { doing speaking activities and interactive dialogues in class; } \\
\square \text { attending lectures and conferences; } \\
\square \text { working in mini-groups of } 5 \text { to } 7 \text { students; } \\
\square \text { only individually. }\end{array}$ \\
\hline $\begin{array}{l}\text { 5. Are you satisfied with the way the training } \\
\text { material is provided? Which of the issues } \\
\text { match your taste? }\end{array}$ & $\begin{array}{l}\square \text { range of lesson topics; } \\
\square \text { classroom assignments and practice; } \\
\square \text { training tempo; } \\
\square \text { practicing new words and word combinations; } \\
\square \text { drilling grammar rules. }\end{array}$ \\
\hline What issues appeal to you less? & $\begin{array}{l}\square \text { lack of typical exam tasks; } \\
\square \text { uninteresting topics; } \\
\square \text { lack of speaking and writing practice; } \\
\square \text { no language level division; } \\
\square \text { no conversational practice with native speakers. }\end{array}$ \\
\hline $\begin{array}{l}\text { 7. What additional information would you } \\
\text { like to receive in English classes? }\end{array}$ & $\begin{array}{l}\square \text { more vocabulary enrichment work (e.g. current international and regional news); } \\
\square \text { more grammar patterns explanation; } \\
\square \text { more reading comprehension practice; } \\
\square \text { more listening and watching activities; } \\
\square \text { more practice on writing letters, essays, etc. }\end{array}$ \\
\hline What topic has sunk into your mind? & $\begin{array}{l}\square \text { basic school theme (e.g., "Family and Friends", "My School”, "Hobbies and } \\
\text { Leisure Time”); } \\
\square \text { professionally-oriented theme (e.g., "Ecological Challenges”, "Science and } \\
\text { Technology”, "Healthcare and Medicine”); } \\
\square \text { basic grammar theme (e.g., "Tenses", "Irregular Verbs", "Passive"); } \\
\square \text { specific grammar theme (e.g., "Types of Participles", "Emphatic Constructions”); } \\
\square \text { the recommendations how to write a letter to a pen-friend. }\end{array}$ \\
\hline $\begin{array}{l}\text { 9. Which of the lesson sections was of the } \\
\text { least interest to you? }\end{array}$ & $\begin{array}{l}\square \text { basic vocabulary exercises; } \\
\square \text { professionally-oriented vocabulary exercises; } \\
\square \text { basic grammar tips; } \\
\square \text { specific grammar reference; } \\
\square \text { the guide on successful writing. }\end{array}$ \\
\hline $\begin{array}{l}\text { 10. What training techniques, which you are } \\
\text { not accustomed to, are introduced in your } \\
\text { English classes? }\end{array}$ & $\begin{array}{l}\square \text { analysing of the students' mistakes in person; } \\
\square \text { audio and video practice; } \\
\square \text { application of visual aids for better comprehension; } \\
\square \text { dictation-translation, essay writing; } \\
\square \text { dialogues, role-play activities, presentation projects. }\end{array}$ \\
\hline $\begin{array}{l}\text { 11. What advice can you give to your teacher / } \\
\text { lecturer to improve the training process? }\end{array}$ & $\begin{array}{l}\square \text { to introduce video material, quest and role-play activities; } \\
\square \text { not to set any homework and if there is some, not to check it; } \\
\square \text { to provide the students with individual tasks (according to a language proficiency } \\
\text { level of each student); } \\
\square \text { to create a teacher-centred atmosphere; } \\
\square \text { to create a student-centred atmosphere in class. }\end{array}$ \\
\hline
\end{tabular}


The study showed that $60.2 \%$ of the respondents from Research Group 1 answered the first question of the open-ended questionnaire ("Why do you personally need to study English?") replying "to get ready for the successful EIT passing". But then, in the closed-ended questions only $18.1 \%$ of the university entrants (the same Research Group) chose that answer again. Why did that happen? What caused such a shift in the schoolchildren's priorities? Why did it turn out that other options on this question became more prioritized to the respondents? We believe that schoolchildren personalities are still inconsistent, unaware of the importance of the current situation, full of dreams about travelling and rest, far from focusing on conscientious and persistent exam preparation. In fact, our beliefs have been proved by the poll results.

The same situation refers to the respondents of Research Group 2. Firstly, in the open-ended questions most of them wrote about hard work and perseverance, but when they were given options to choose from (in the closed-ended questionnaire) $56.1 \%$ responded "to speak fluent English while travelling abroad". To sum up, we can claim that both the university entrants and the junior students lack interest for thorough university training. The analyses and results obtained allowed us to evaluate the students' motivation to studying as rather low. Since we were unable to change either the course curriculum or the topics, we decided to boost the students' interest by implementing mind-mapping techniques in class.

As for Research Group 3, we saw quite a different situation. It appeared that $88.6 \%$ of the respondents chose the option "successful career opportunities in the future" in both types of the questionnaires - the open and closed-ended ones. The data obtained showed that only $5.7 \%$ of respondents answered "to speak freely in a FL environment while travelling abroad" and "to study abroad". This is a statistical evidence of the participants' awareness what goals to set and which decisions to make. Although it may seem that the respondents of this group are the personalities with a ready-made life platform and accumulated experience, they also lack much interest to study and enhance their language skills.

Comparing the same option in the questionnaire chosen by the respondents of Research Groups 1 and 2, it can be stated that $39.7 \%$ and $31.1 \%$ correspondingly study English for a successful future career. It should be noted that both the university entrants and the students of the first year are not going to study abroad.

The next question concerned the level of English proficiency that the respondents were asked to indicate. The following results were obtained: $53.4 \%$ of the respondents from Research Group 1 and $62.2 \%$ of Research Group 2 are Intermediate (B1), 18.1\% and 37.8\% accordingly are Upper-Intermediate (B2), and $80 \%$ of the respondents from Research Group 3 are also
Upper-Intermediate (B2). Only 20\% of the fourth-year students are advanced (C1) in English. The data were also proved by the test results. It is worth highlighting the fact that according to the curricula of the Ukrainian secondary (not in-depth study) schools, an average pupil is required B1 English, but the results of the tests, taken in class, did not prove it.

It seems to be relevant to comment here on Question 6 - "What additional information would you like to receive in English classes?” The students of the first and fourth years are unwilling to obtain more grammar rules in classes. While interviewing the respondents it was found out that they are completely satisfied with the grammar rules taught within the university English courses. The students believe that there is no need to demand deeper grammar drilling. On the other hand, $14.7 \%$ of the university entrants agreed on such an option. If we consider the current challenges at the Ukrainian secondary school such as the lack of English lessons for the sufficient EIT exam preparation, it becomes evident why the school teachers fail to pay enough attention to this issue, so schoolchildren are unlikely to learn more grammar.

Most respondents showed quite positive attitude towards such training activities as videos, presentations, quizzes, quests and role-playing games. However, the above-polled students regretted having just a little experience of these techniques in class, which is confirmed by the teachers who were also interviewed selectively. Such a gap between the students' keen interests and the lesson plans is explained by the lack of time, as well as the requirements of the subject curriculum (see Table 2).

Summing up the survey results, we can claim that most students are eager to learn English, be fluent in it, express their thoughts in a perfect grammar, show a rich vocabulary, and be an interesting interlocutor. However, according to the questionnaire results, it has been found out that the students do not become advanced as quickly as they would like. Moreover, they strongly believe that the main reason of their slow language proficiency development is inefficient training materials provided in class. Therefore, to help the students achieve their goals, we assumed that the mind-mapping training technique along with other innovative techniques would ameliorate the situation, which in turn, would streamline the teaching methods used in the ESP course. So, all respondents from Research Groups 1-3 were divided into control and experimental groups. The number of participants in each group, as well as the level of their English, was the same. The training remained traditional in the control groups, but as for the experimental ones, the mind maps were introduced into their key practicing activities. 
Table 2. Closed-Ended Questionnaire Results of the University Entrants, the Junior Students and the Fourth-Year Students, \%

\begin{tabular}{|c|c|c|c|c|c|c|c|c|c|c|c|}
\hline \multirow{2}{*}{$\begin{array}{l}\text { Response } \\
\text { Options }\end{array}$} & \multicolumn{11}{|c|}{ Question Number } \\
\hline & 1 & 2 & 3 & 4 & $5 / 1$ & $5 / 2$ & 6 & 7 & 8 & 9 & 10 \\
\hline \multicolumn{12}{|c|}{ Closed-Ended Questionnaire Results of the University Entrants, \% } \\
\hline 1 & 18,1 & 10,4 & 60,3 & 31,9 & 18,1 & 10,4 & 10,3 & 21,6 & 14,7 & 18,1 & 61,8 \\
\hline 2 & 6,9 & 18,1 & 39,7 & 0 & 28,4 & 0 & 31,9 & 10,3 & 18,1 & 38,8 & 3,4 \\
\hline 3 & 35,3 & 53,4 & 0,0 & 53,4 & 3,5 & 6,9 & 14,7 & 18,1 & 38,7 & 10,3 & 18,1 \\
\hline 4 & 0 & 18,1 & & 14,7 & 35,3 & 29,3 & 28,4 & 6,9 & 21,6 & 18,1 & 14,7 \\
\hline 5 & 39,7 & 0 & & 0 & 14,7 & 53,4 & 14,7 & 43,1 & 6,9 & 14,7 & 2,0 \\
\hline \multicolumn{12}{|c|}{ Closed-Ended Questionnaire Results of the Junior Students, \% } \\
\hline 1 & 0 & 0 & 18,9 & 43,9 & 0 & 0 & 62,8 & 0 & 25,0 & 12,2 & 25,0 \\
\hline 2 & 12,8 & 0 & 81,1 & 6,1 & 0 & 0 & 0 & 87,8 & 0 & 0 & 62,8 \\
\hline 3 & 56,1 & 62,2 & 0 & 37,8 & 62,8 & 0 & 0 & 0 & 75,0 & 50,0 & 0 \\
\hline 4 & 0 & 37,8 & & 12,2 & 25,0 & 0 & 6,1 & 6,1 & 0 & 0 & 0 \\
\hline 5 & 31,1 & 0 & & & 12,2 & 100 & 31,1 & 6,1 & 0 & 37,8 & 12,2 \\
\hline \multicolumn{12}{|c|}{ Closed-Ended Questionnaire Results of the Fourth-Year Students, \% } \\
\hline 1 & 0 & 0 & 0 & 20,0 & 0 & 0 & 31,4 & 0 & 34,3 & 14,3 & 0 \\
\hline 2 & 0 & 0 & 100 & 20,0 & 100 & 0 & 0 & 74,3 & 0 & 0 & 45,7 \\
\hline 3 & 5,7 & 0 & 0 & 60,0 & 0 & 0 & 0 & 0 & 65,7 & 31,4 & 54,3 \\
\hline 4 & 5,7 & 80,0 & & 0 & 0 & 14,3 & 0 & 0 & 0 & 0 & 0 \\
\hline 5 & 88,6 & 20,0 & & 0 & 0 & 85,7 & 68,6 & 25,7 & 0 & 54,3 & 0 \\
\hline
\end{tabular}

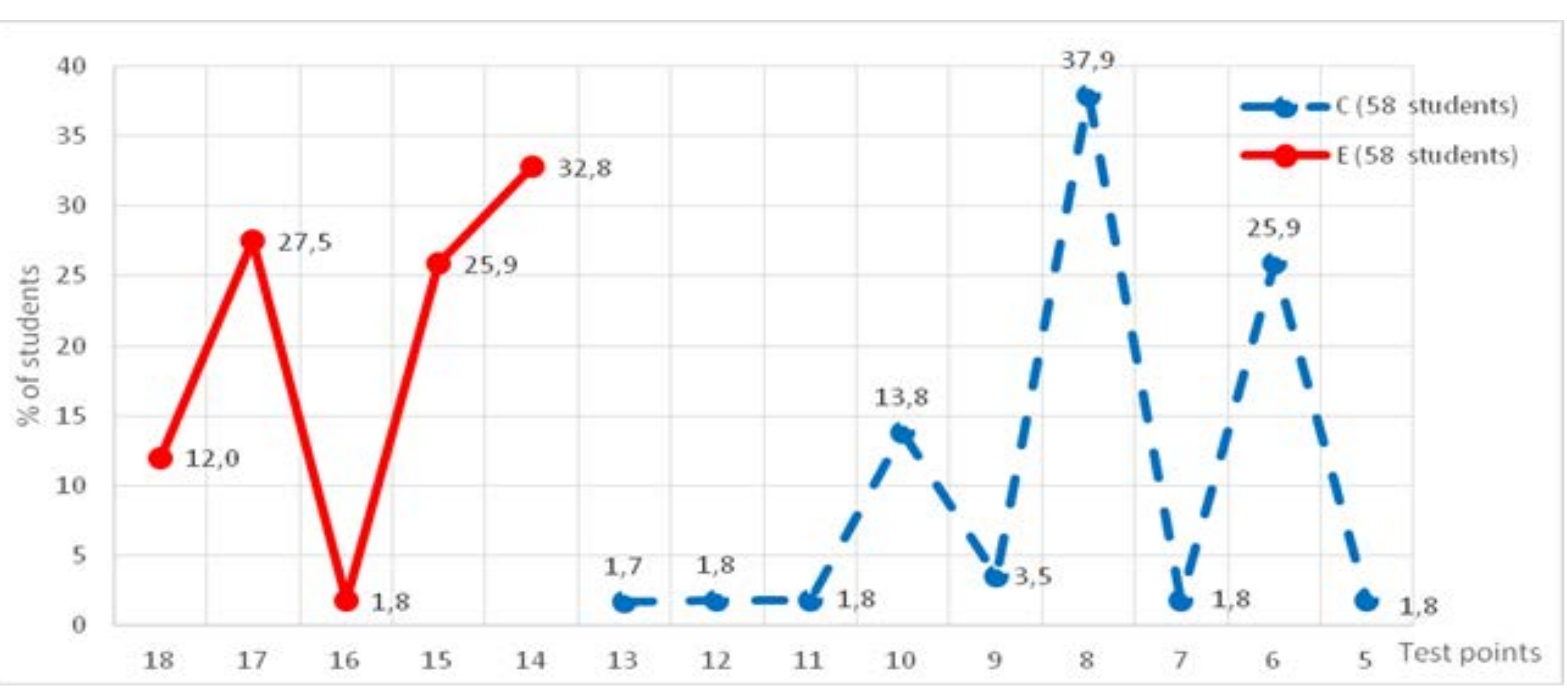

Figure 1. Testing results of vocabulary skills development of Research Group 1 (at the formative stage of the experiment, \%)

Research Group 1 encompassed the control (C1-3) and experimental groups (E1-3) with 58 pre-university students in each of them. The results of the tests done are shown in Figure 1.

As we can see, Figure 1 depicts the difference between the control and experimental groups' test results concerning the university entrants' volume of vocabulary skills development. The respondents from C1, C2, C3 groups scored only from 5 to 13 points (the biggest quantity of respondents, $37.9 \%$, got 8 points in testing), while the students from E1, E2, E3 groups - in the range from 14 to 18 points (32.8\% of them scored 14 points in tests). Such a difference in the obtained results proves the relevance of the mind-mapping training method, practiced at the lessons in E1, E2 and E3 groups. One of the mind maps, introduced in class, is shown in Figures 2 and 3. Such a result was obtained in the 2016-2017 academic year while training the groups of the university entrants at the Preparatory Department (for the Ukrainian citizens) of Taras Shevchenko National University of Kyiv. This was also proved by the EIT examination results in English, because the university entrants received the certificates with rather high score - from 178 to 189 points.

Research Group 2 encompassed 4 control (C1-4) and 4 experimental (E1-4) groups with the fixed number of the respondents. And again the test preparation in the control groups was carried out without any teaching innovations, that is, for example, by word combinations exercising, traditional pre-reading and reading tasks, after-reading discussion, etc. The experimental groups were preparing for the test, practicing a new vocabulary on the topic "Fears and Techno Phobias" by means of the mind maps (see Figure 4). The test results are shown in Figure 2. 


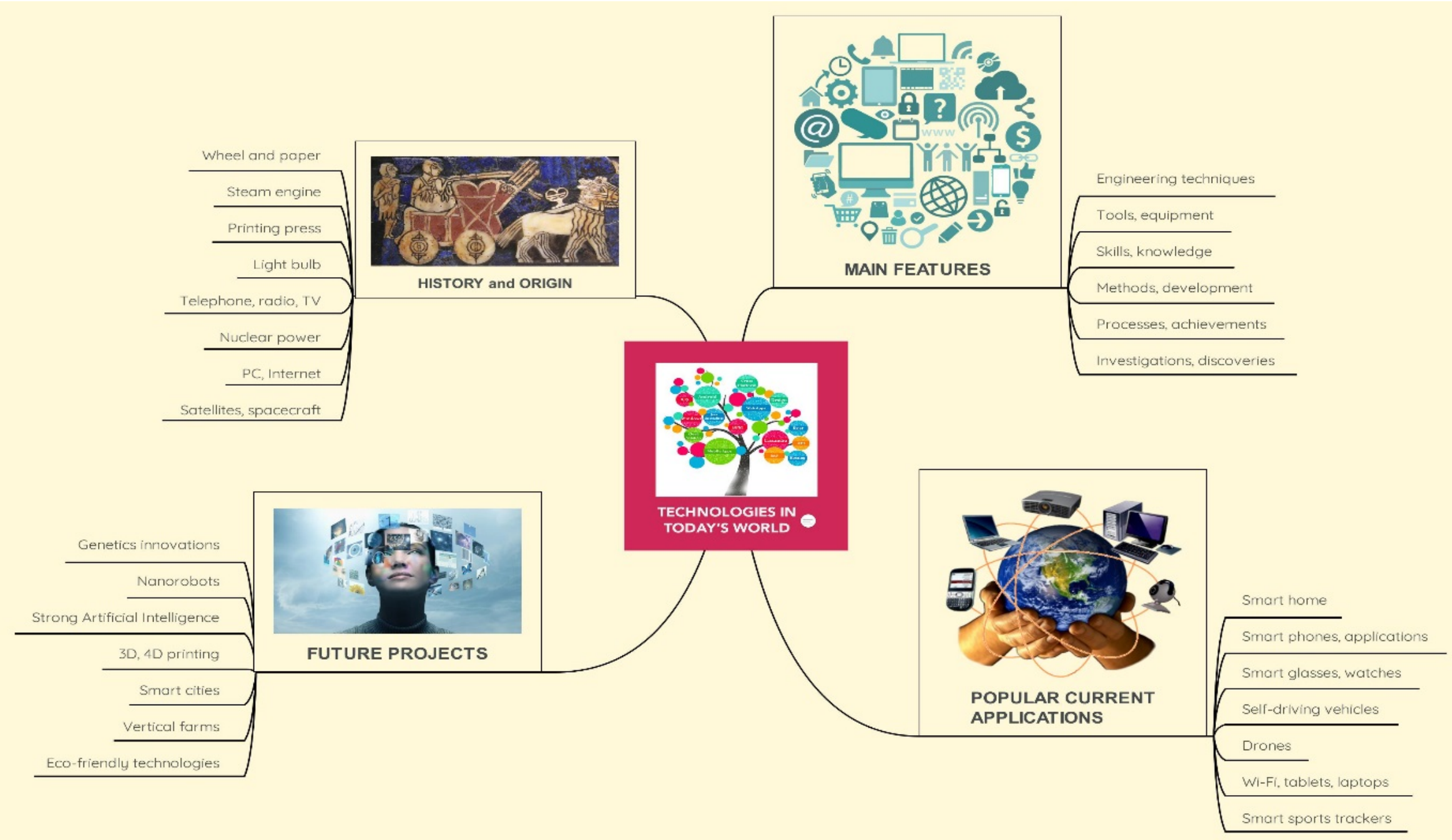

Figure 2. Mind Map on Topic “Technologies in Today’s World”, practiced by the experimental groups from Research Group 1 


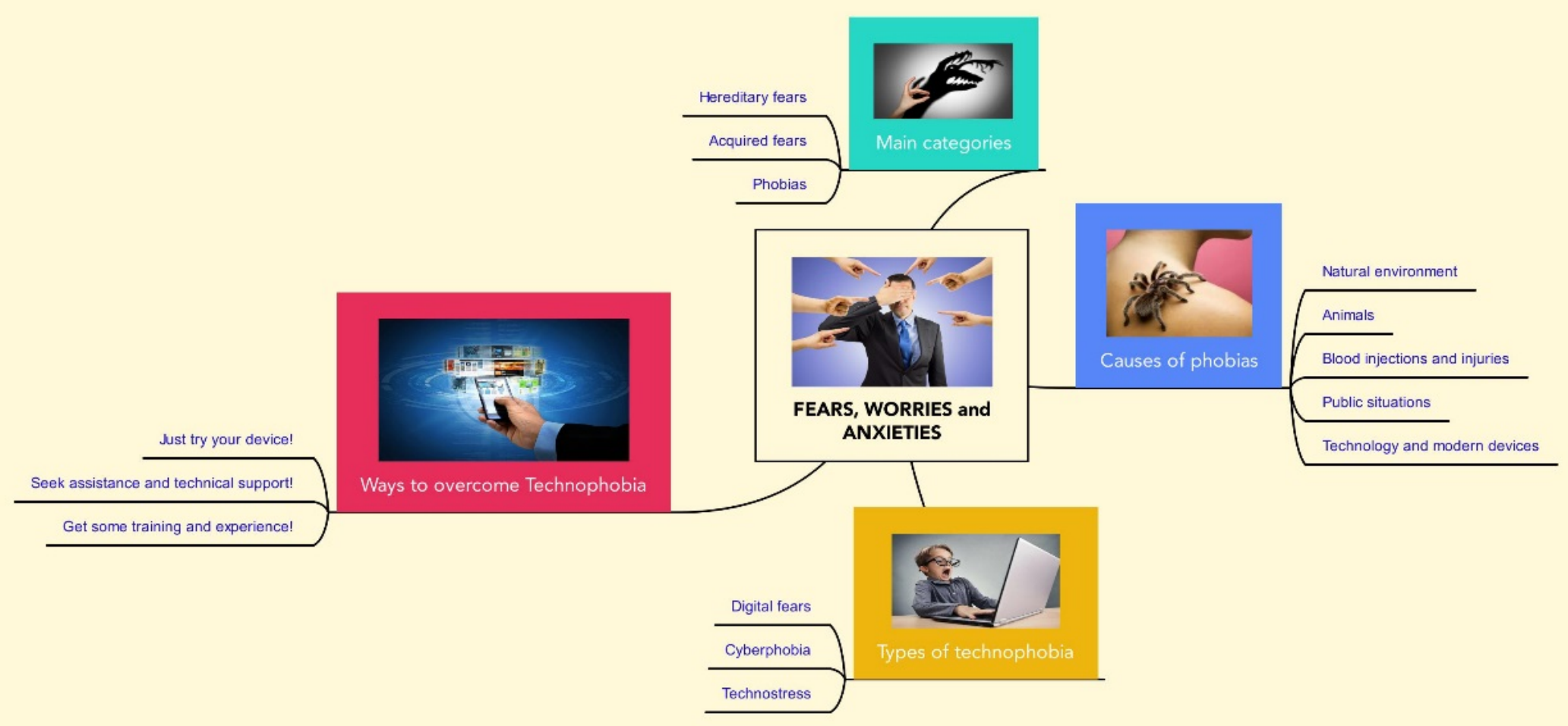

Figure 3. Mind Map on Topic "Fears and Techno Phobias", practiced by the experimental groups from Research Group 2 


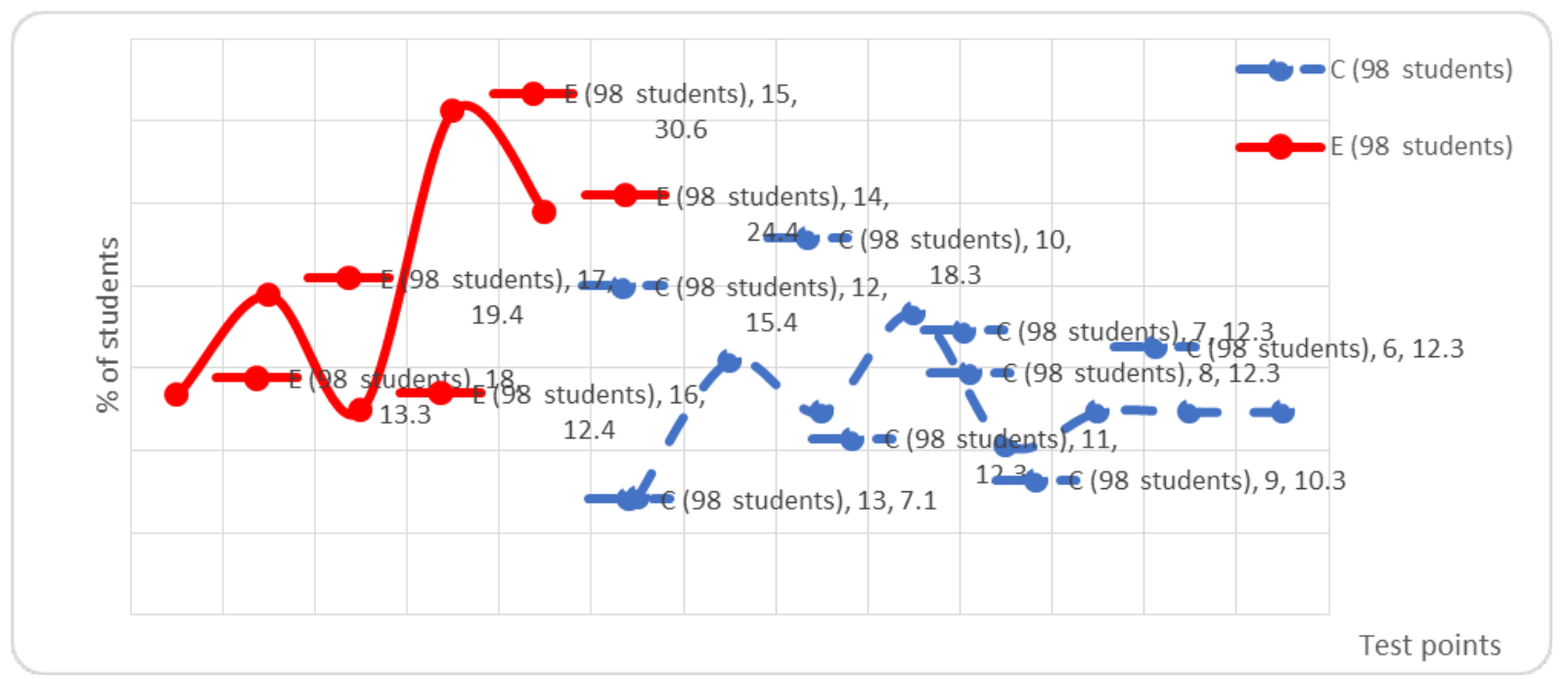

Figure 4. Testing results of reading skills development of Research Group 2 (at the formative stage of the experiment, \%)

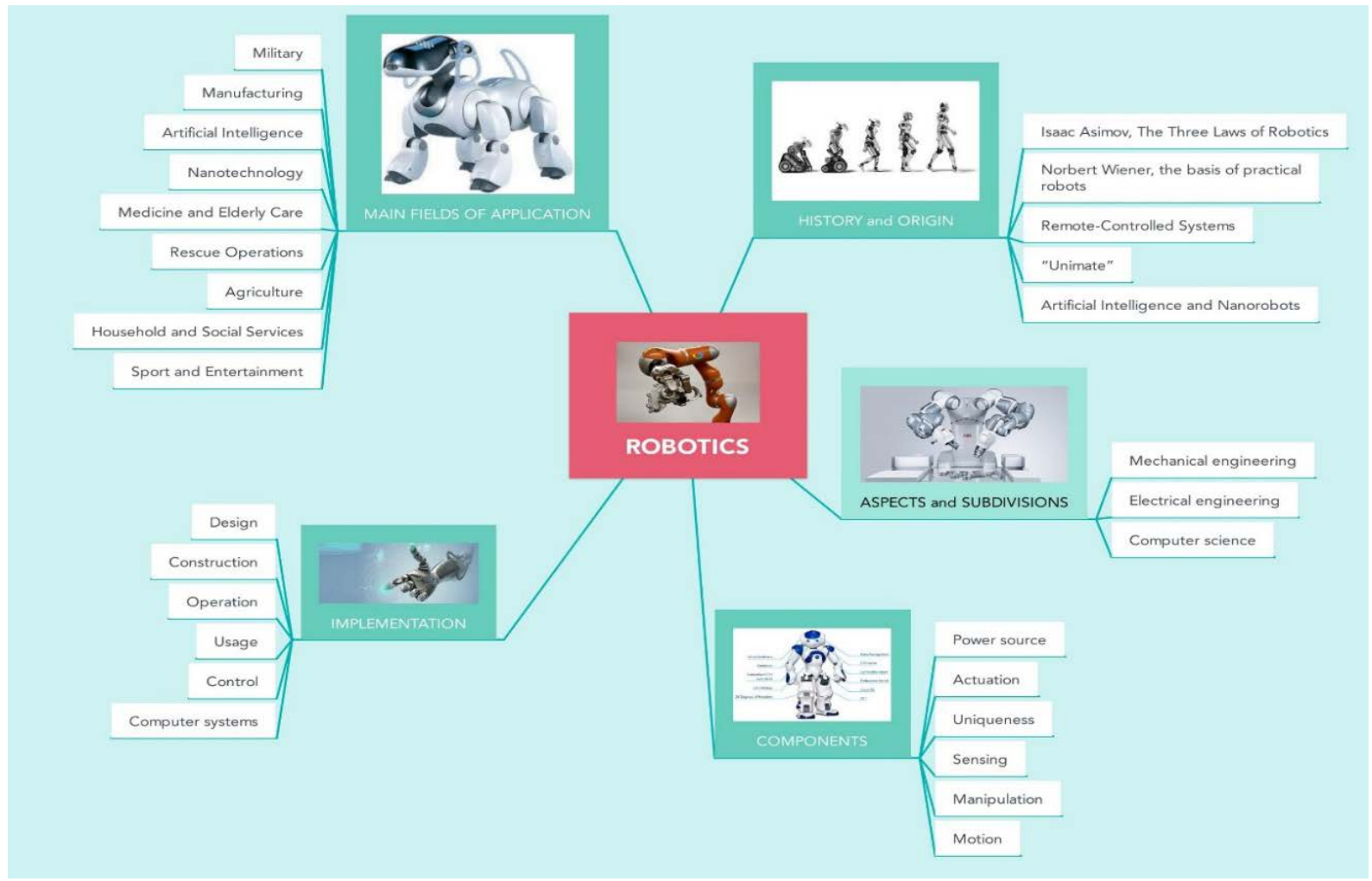

Figure 5. Mind Map on Topic “Robotics”, practiced by the experimental groups from Research Group 3

As shown in the figure 4, the test results, obtained by the participants of control and experimental groups, are different: in C1-4 each of $12.3 \%$ of the students scored 6 , 7 and 8 points and showed the weakest results, and the least quantity of $7.1 \%$ got the highest result in 13 points. Accordingly, within E1-4 the results are far better: $24.4 \%$ of the participants got 14 test points (the lowest result) and $13.3 \%$ - 18 points (i.e. the highest result in the group).

As for the respondents from Research Group 3, their number was 17 students in the control group and 18 in the experimental one. Figure 5 in shows a mind map for the topic "Robotics", worked out by the fourth year students of the experimental group on their own and then practiced in class as a pre-test preparation.

Figure 6 depicts the test results of the respondents from Research Group 3.

The data shown in the figure above depict that the test points, scored by the students of $\mathrm{C} 1$, are significantly lower than those ones of E1. Not a single participant from C1 managed to get a 'very good' mark, the biggest quantity of the students (17.6\% and $35.3 \%)$ scored 
correspondingly $9 / 13$ and 10 points. As for E1, it is vivid that $16.7 \%$ and $27.8 \%$ obtained correspondingly $16,17 / 18$ points (i.e. 'very good' results); $16.7 \%$ and $11.1 \%$ scored even 19-20 test points, showing 'excellent' according to the grading scale.

The research results show that the tests completed by the participants from Research Group 1 were assessed in 14 to 18 points out of 20 (E1-3) and in 5 to 13 points in C1-3, correspondingly. The students from Research Group 2 also received from 14 to 18 test points in E1-4, and from 6 to 13 points in the corresponding control groups. As it can be seen, the test scores received by the university entrants and the junior students are almost the same. Although the number of junior students, taken the test, is far bigger than that of the university entrants, the qualitative aspect of language development needs to be improved. As for Research Group 3, there is an increasing tendency to more profound self-development and language skills boosting in E1, considering the points its participants obtained. The exact number of points gained is: 16 (3 students), 17 (5 students), 18 (5 students), 19 (3 students) and 20 (2 students).

The findings define an average grading score in each Research Group. In C1-3 of Research Group 1 it is 7,12 and in E1-3 this score is 15,6 . So, we can see that academic performance of the students practiced mind-maps is more than twice as high as in the control groups (particularly, it is higher by 119\%). Research Group 2 shows the following average grading score: 9,46 in C1-4 and 15,65 in E1-4. Consequently, academic performance due to the mind-mapping teaching technique implementation has been improved by $65 \%$. The average grading score data of Research Group 3 are as follows: 10,7 in C1 and 17,8 in E1. Significant is the increase of academic performance by $66 \%$. Such an improvement in language performance results proves the relevance of the mind-mapping training method, practiced at the lessons within all experimental groups.

The results obtained at the formative stage of the conducted experiment could be explained in the following way: the control groups were trained based on the traditional methods of teaching, which can be called linear, the students comprehend the training material gradually. As it has been proved above, they fail to predict the final result. On the contrary, the experimental groups perceive the information radially, because the whole material is depicted and presented on one slide (or a paper sheet). Due to the fact that the training tasks visualization enhances their language comprehension up to $80 \%$, the respondents' perception correlates with the principle of the radial thinking theory, which refers to the associative mental process with the starting point and emphasis on the central (core) object. As a result, the mental activity of the experimental groups' respondents from all Research Groups 1, 2 and 3 is capable of producing an endless variety of associative images, which the participants perceive "naturally" fast and easily, and, consequently, memorize rather effectively. While the students from the experimental groups perceive such a high percentage of information visually, they succeed in keeping it in a long-term memory, reproducing on the spot, developing related knowledge and improving their English professional vocabulary much better and more efficiently. The results obtained and the statements made have proved the research working hypothesis suggesting the idea that mind-mapping teaching techniques enable to intensify the learning process by boosting motivation and enhancing language skills of the students with different levels of FL proficiency.

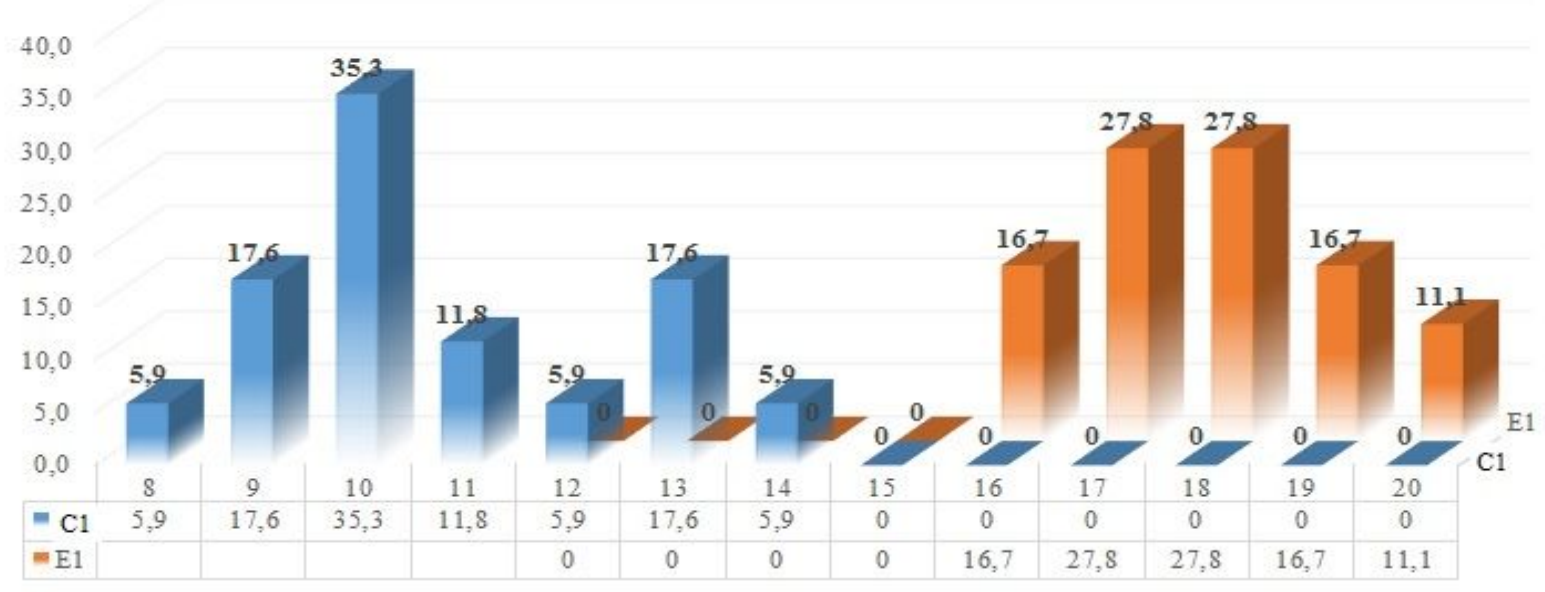

Figure 6. Testing results of listening skills development of Research Group 3 (at the formative stage of the experiment, \%) 


\section{Discussion}

Due to the fact that Professor Anthony's definition of ESP course is a specific "approach to teaching" (Anthony, 2017, p. 18) seemed, from our point of view, rather vague, we found it relevant to specify this concept by the mind-mapping teaching technique implementation. The research conducted made it possible to broaden the studies of K. Huang (Huang, 2016), H. Neil, N. Johnson and P. Lyddon (Neil, Johnson, Lyddon, 2016) on the example of the mind-mapping teaching method of the ESP at one of the top Ukrainian universities.

In our study we distinguished the principle of mind mapping from that one of concept or cognitive maps, worked out by Edward Tolman (Tolman, 1948) and Joseph Novak with Alberto Cañas (Novak, Cañas, 2008). We applied to the mind maps' principle - to describe a single conceptual term with around-developed and intuitively linked ideas - but not to the concept maps' hierarchy of family-tree diagrams, practiced by S.Tümen and M.Taşpinar, in particular (Tümen, Taşpinar, 2007). The experiment made resulted in creating such a psychological environment which encouraged the participants to render the earlier obtained knowledge on their major into yet unknown English terms and concepts in a faster and more effective way.

Our experiment on practical implementation of mind maps slightly differs from D. Šulovská's non-traditional training methods within ESP courses (Šulovská, 2010). In Professor Šulovská's findings, concept maps' application facilitates students with note-taking or new knowledge creation schemes. This principle appeared to be irrelevant in our study because the research participants aimed to form the professional vocabulary bank in English by linking and arranging new ideas around one already familiar to them conceptual centre. It would be unnecessary and rather time-consuming to create any new knowledge for them. On the contrary, we aimed to encourage the students to brainstorm in ESP class the already acquired professional information. A non-traditional way of knowledge structuralizing did not frighten them because of its schematic principle of ideas' visualization, particularly common for a mathematical way of thinking.

According to A. Erdem, mind maps may be taught to students at different levels for note-taking, summarizing, evaluating, determining their targets and expressing themselves in order to improve imagination and develop creative thinking and holistic views (Erdem, 2017). Other scholars, N. Hidayati, S. Zubaidah, E. Suarsini, H. Praherdhiono also state that Digital Mind Maps together with Problem-based Learning stimulate critical thinking and creativity through implementation of the combined model which has been confirmed using an essay test. (Hidayati, Zubaidah, Suarsini, Praherdhiono, 2019).

Another innovation was to apply ESP teaching to such a large audience of the experiment participants - the students of different years of studying, from the pre-university to the Bachelor degree level, and, on the other hand, research material, encompassing a variety of classroom activities. Such a blended quantitative and qualitative approach made the research complex and complete and the results persuasive. For the first time it is revealed that mind maps' practice motivates the students to perform in ESP class better compared to traditional training. Taking into account the data obtained on the positive dynamics of the students' academic performance, it seems logical to assume that motivation boost is one of the most fruitful results of such a non-traditional class implementation.

\section{Conclusions}

The results obtained show the students' FL proficiency improvement. It is the mind-mapping training technique that contributes to radial thinking activation. We are inclined to conclude that the brain reproduction of associative images develops the ability of the students from the experimental research groups to comprehend and learn training material in a "natural" way, thus, relatively easily, quickly and effectively comparing to the results gained from the corresponding control groups. Above all, information visualization facilitates current topic re-structuring, highlights important aspects, establishes new logical bonds between key concepts, and reveals related issues. The students' motivation to do better at the lesson is enhanced.

Hence, such a non-traditional approach in ESP classroom proves to enlarge FL academic performance and thus, to be more effective in FL learning and practice compared to traditional training methods. It would be useful to carry out further investigation of fundamental templates of mind maps' content structuring within other pressing issues of the ESP university course.

\section{REFERENCES}

[1] Anthony, L. (2018). Introducing English for Specific Purposes. Abingdon, UK: Routledge Press. DOI:10.4324/9781351031189

[2] Ausubel, D. P. (1968). Educational Psychology: A Cognitive View. New York, US: Holt, Rinehart \& Winston.

[3] Bakaeva, H., Borysenko, O., Zuenok, I. \& others (2005). Anhliys'ka mova dlya spetsial'nykh tsiley [English for Specific Purposes] (ESP) National Curriculum for Universities. Kyiv, Ukraine: LENVIT. [in Ukrainian]

[4] Karpushyna, M., Bloshchynskyi, I., Nakonechna, A., Skyba, K. (2019) Creating Meaningful Foreign Language Environment by Means of Content-based Starters. Universal Journal of Educational Research 7.122710 - 2716. doi: 
10.13189/ujer.2019.071219.

[5] Navchal'na prohrama z anhliys'koyi movy dlya spetsial'nykh kursiv dlya ukrayins'kykh universytetiv [Curriculum on English for Specific Purposes Courses for the Ukrainian Universities] (2013). URL: http://vzvo.gov.ua/navchalni-pr ohramy.html. [in Ukrainian]

[6] Downs, R. M \& Stea, D. (1977). Maps in Minds: Reflections on Cognitive Mapping. New York, US: Harper \& Row.

[7] Huang, K. (2016). Current Developments in English for Academic and Specific Purposes: Local Innovations and Global Perspectives. English for Specific Purposes International Journal, 44, 84-86. DOI: 10.1016/j.esp.2016.0 4.005

[8] Kolesnyk, I. (2012). Mental'ne kartohrafuvannya ta profesiya istoriyi: mizh ratsional'nym y uyavlenym. [Mental Cartography and the Profession of a Historian: between Rational and Figurative Entities]. Ukrayins'kyy istorychnyy zhurnal Kyiv, Ukraine, 5, 135-156. URL//history.org.ua/Jo urnALL/journal/2012/5/11.pdf [in Ukrainian]

[9] Mashkina, V. V. (2011). Vikorystannya mental'nykh kart u pidhotovtsi fakhivtsiv $\mathrm{z}$ heohrafiyi [Use of mental maps in training of specialists in geography] Problemy bezperervnoyi heohrafichnoyi osvity i kartohrafiyi, [Issues of Full-Time Geographical Education and Cartography], Kharkiv, Ukraine, 13, 62-64. URL: http://goik.univer.khark ov.ua/ua/archive/_[in Ukrainian]

[10] Neil, H., Johnson, P. \& Lyddon, A. (2016). Teaching Grammatical Voice to Computer Science Majors: The Case of Less Proficient English Learners. English for Specific Purposes International Journal, 41, 1-11. DOI: 10.1016/j.esp.2015.08.001

[11] Novak, J. D. \& Cañas, A. J. (2008). The Theory Underlying Concept Maps and How to Construct and Use Them. Florida Institute for Human and Machine Cognition. URL: https://web.stanford.edu/dept/SUSE/projects/ireport/articles /concept_maps/The\%20Theory\%20Underlying\%20Concep t\%20Maps.pdf

[12] Pak, N. I. (2010). Informatsionnoye modelirovaniye [Information Modelling]. RF, Krasnoiarsk: KGPU named after V.P. Astafiev. [in Russian].

[13] Pozdniakova, T. (2018). Visualization and Structuring of Information by Means of Mind Maps at the Lessons of Biology. Rivne, Ukraine: ROIPPE. URL: http://umo.edu.ua /images/content/depozitar/posibnyky/navchalyni [in Ukrainian]

[14] Rebenko, M. Yu. (2017). Anhliyska mova dlya profesiinyh tsilei [English for Specific Purposes] Curriculum for Undergraduates of Computer Science and Cybernetics Faculty. Kyiv, Ukraine: Kyiv University. [in Ukrainian]

[15] Schenk, F. (2013). Mental Maps: Die kognitive Kartierung des Kontinents als Forschungsgegenstand der europäischen Geschichte [Mental Maps: The Cognitive Mapping of the Continent as a Research Object of the European History]. Europäische Geschichte Online. URL: http://www.ieg-ego. eu/schenkf-2013-de.

[16] Shakhina, I. \& Miedviediev, R. (2015). Vykorystannya mental'nykh kart u navchal'nomu protsesi. [The Use of Mental Maps in Training Process]. Scientific Notes, 8(3), 73-78. URL: https://phm.cuspu.edu.ua/ojs/index.php/NZ-P MFMTO/article/viewFile/19/16. [in Ukrainian]

[17] Shatalov, V. F. (1989). Eksperiment prodolzhayetsya [The Experiment Is Under Go]. Moscow, RF: Pedagogika.

[18] Šulovská, D. (2010). Kvalita jazykového vzdelávania na univerzitách v Európe 3 [elektronický zdroj], [Concept maps in the ESP classroom]. 208-215. URL: http://www.academia.edu/25388401/CONCEPT_MAPS_I N_THE_ESP CLASSROOM

[19] Tolman, E. C. (1948). Cognitive Maps in Rats and Men. Psychological Review, 55(4), 189-208. URL: http://psychclassics.yorku.ca/Tolman/Maps/maps.htm.

[20] Tverezovska, N. (2017). Information Resources Enabling Social-Pedagogical Activities. Kyiv, Ukraine: Komprint.

[21] Tümen, S., \& Taşpinar, M. (2007). The Effects of Concept Mapping on Students' Achievements in Language Teaching. $7^{\text {th }}$ International Educational Technology Conference (IETC), 375-382. URL: https://files.eric.ed.gov/fulltext/ED 500143.pdf.

[22] English for Specific Purposes: An International Journal. URL: https://www.journals.elsevier.com/english-for-specifi c-purposes.

[23] Website of Iryna Olexandrivna Chereshniuk. Source: URL:http://irinaclass12.dp.ua/2016/10/14/ментальна-карта /.

[24] Woolfolk, A. E., Winne, P. H., Perry, N. E., \& Shapka, J. (2010). Educational Psychology. Toronto, Canada: Pearson Canada.

[25] Common European Framework of Reference for Languages: Learning, Teaching, Assessment, 265. URL: https://rm.coe. int/CoERMPublicCommonSearchServices/DisplayDCTMC ontent?documentId=0900001680459f97

[26] Erdem, A. (2017). Mind Maps as a Lifelong Learning Tool. Universal Journal of Educational Research, 5(12A), 1 - 7. DOI: 10.13189/ujer.2017.051301.

[27] Hidayati, N., Zubaidah, S., Suarsini, E., Praherdhiono, H. (2019). Examining the Relationship between Creativity and Critical Thinking through Integrated Problem-based Learning and Digital Mind Maps. Universal Journal of Educational Research, 7(9A), 171 - 179. DOI: 10.13189/ujer.2019.071620. 